\title{
John Wesley Elkins, Boy Murderer, and His Struggle for Pardon
}

\author{
PATRICIA L. BRYAN
}

However dwarfed and distorted, even hidden for a time, the moral sense can never be entirely eradicated from any human breast, and Wesley Elkins, moral idiot and boy murderer, still contained possibilities, which needed only the opportunity of development. And as strange as it may seem, these opportunities, hitherto lacking, he found within the walls of the penitentiary....

But, you may ask, is not all improvement superficial? Has the real root of the matter been touched? Is it indeed possible to arouse the moral sense of the degenerate or moral idiot? ${ }^{1}$

IN EARLY SEPTEMBER 1901, the Anamosa Prison Press, a newspaper written and published at the Iowa State Penitentiary at Anamosa, reported that one of their own "reeled and fell in a

I am indebted to Richard Snavely and Steve Wendl, both of the Anamosa State Penitentiary Museum, for their friendship and their invaluable contributions to this article. They alerted me to the story of Wesley Elkins, encouraged my work, and generously shared information and ideas. I am also grateful to Ilo Rhines and Judy Moyna for their investigation into Elkins's life after his release; the staff at the State Historical Society of Iowa in Des Moines, especially Gordon Hendrickson, Jeffrey Dawson, and Sharon Avery, for their help during my search of the archives there; my excellent research assistants, particularly Ben Iddings, Taylor Browne, and Morgan Stoddard, for their diligent research and many other contributions; Marvin Bergman and three anonymous reviewers of an earlier draft of this article for their valuable comments; and Thomas Wolf, for his unfailing support of this project. My work on this article was supported, in part, by grants from the State Historical Society of Iowa and the North Carolina Law Center Foundation.

1. E. Wade Koons, "Wesley Elkins," Coe College Courier, 12/12/1899. This essay won the Dow's Prize, awarded at Coe College, June 1899.

THE ANNALS OF IOWA 69 (Summer 2010). (C) The State Historical Society of Iowa, 2010. 
faint," collapsing among lines of convicts on their way to dinner. ${ }^{2}$ Identified only as \#1900, the stricken man was well known at Anamosa as one of the small group of "lifers," those sentenced to the longest possible term behind bars. Prisoner \#1900 had already been incarcerated for more years than most, although he was also one of the younger men there, with his youth accentuated by his slight physique: he stood 5' 2" tall and weighed 110 pounds. Only 24 years old, Prisoner \#1900 had spent nearly 12 years at Anamosa - almost half his life. ${ }^{3}$

People throughout Iowa would have recognized him by name. He was John Wesley Elkins, the notorious "boy murderer" from Clayton County who had been convicted of firstdegree murder for killing his father. At the age of 11, Elkins had shot his sleeping father in the head with a rifle. When his stepmother tried to help her dying husband, Elkins used a wooden club to beat her to death. Those at the penitentiary in Anamosa, though, knew him as their conscientious head librarian, a job he had held since 1894. In 1901 the Prison Press described him as a "bright, observing youth" with "a fund of book lore which would be a credit to any man." Prison officials shared that positive impression. They recognized Elkins's intelligence and education and appreciated his excellent record of conduct. During his years at Anamosa, he had matured from a shy and fearful child into a literate and articulate young man, well-read, thoughtful, and capable of eloquent expression. ${ }^{4}$

The long period of confinement, though, was taking its toll on Elkins. After his fainting spell, doctors concluded that "the

\section{Anamosa Prison Press, $9 / 7 / 1901$.}

3. Des Moines Daily Capital, 4/21/1902. From 1891 to 1899, the average age of prisoners sent to Anamosa was about 30. State Board of Control, Biennial Report (1899), 366. In 1901-02, the Anamosa penitentiary's population was approximately 400, with 40 of them serving life sentences. Anamosa Prison Press, 2/1/1901. In 1904 it was reported that out of 49 lifers, only a very few had served more than ten years, since "the lifers, apparently, do not live long." Cedar Rapids Weekly Gazette, 4/14/1904. According to the Prison Press, 2/1/1902, the men serving life sentences were invariably "the best behaved prisoners in a prison."

4. Elkader Register, 1/16/1890; Anamosa Prison Press, 9/21/1901; Wesley Elkins: An Appeal and Statements of Ex-Wardens Barr and Madden and Warden Hunter (1902), Cornell College Archives, Mount Vernon, Iowa. 
boy's nervous system is in a weak condition." He was hospitalized for a few days and kept under observation. When he was discharged, he was transferred from the library to work in the engine room, with the hope that a change of scene would raise his spirits and improve his health. ${ }^{5}$

At the time, Elkins was about to embark on the next phase of a battle that had consumed him for years. He was fighting for his freedom, arguing that he deserved to be released from prison. By 1901, he had gained the support of influential men who publicly advocated for his cause, and yet they knew that this appeal would trigger another firestorm of protest. Once again, he would be portrayed as a degenerate, born with a defective moral sense that could not be corrected. Residents of Clayton County, scene of the crimes, had always been especially vehement in their opposition to Elkins's release, claiming to have proof of his bad heritage and uncontrollable violent tendencies. In their minds, he was a born criminal whose nature could be masked but never changed. The strength of those views had condemned him to continued incarceration. ${ }^{6}$

Elkins never denied his role in the killings or retracted the confession that had led to his murder conviction and life sentence. He argued, though, that those legal consequences were too extreme to impose on an 11-year-old who lacked the requisite mental capacity for criminal intent and so could not be held responsible in the same way as an adult. He described his deeds as the impulsive acts of a child at an early stage of development and strongly affected by parental mistreatment and neglect. ${ }^{7}$

5. Anamosa Prison Press, 9/7/1901, 9/21/1901.

6. Des Moines Daily Leader, 3/19/1902.

7. See, for example, Cedar Rapids Republican, 1/23/1898. Elkins's argument that his sentence was too extreme for a child was well supported by legal precedent. See State v. Aaron, 4 N.J.L. 231 (1818), describing the established rule that children under the age of 7 were presumed unable to discern the difference between good and evil and thus were incapable of committing capital crimes; the same presumption applied to children between the ages of 7 and 14, and could be overcome only by strong and convincing evidence that the child could comprehend the nature and consequences of his act. Other precedent supporting lessened criminal responsibility for children under the age of 14 is discussed in Anthony M. Platt, The Child Savers: The Invention of Delinquency (Chicago, 1977), 193-212. 
Although he was unwilling to accept a life sentence, Elkins admitted that he had done wrong. Imprisonment had punished him for that, but his years inside the penitentiary walls had offered him more than the chance to repent and atone for his crimes. In the true spirit of a reformatory, Anamosa had given him the means necessary to develop the mature moral consciousness of a law-abiding adult, and now his rehabilitation was complete. As Elkins argued in persuasive appeals, which were publicized throughout the state, no societal purpose could be served by his continued incarceration. ${ }^{8}$

These arguments resonated with many progressive thinkers of the time, who were convinced that the possibility of rehabilitation offered a solution to the serious problem of crime. On the other hand, many people, drawing on scientific theories from the previous century, believed that criminal conduct resulted from a congenital brain defect, with the affliction isolated to the moral faculty, or the capacity to distinguish between right and wrong. Seeking to explain the disability, commentators often blamed heredity, suggesting that criminality might be an inherited trait, developed through evolutionary forces. The emerging picture of a "moral imbecile" was chilling: an individual, normal in outward appearance and often highly intelligent, who was subject to innate and uncontrollable urges to commit terrible acts of depravity. ${ }^{9}$

By the end of the nineteenth century, two very different images of criminals loomed in the popular imagination. In one image, the offender was driven to crime by bad associations and other negative external forces and could be reformed through education, hard work, and guidance. In opposition lurked a darker prototype: the born criminal, with an inherited degenerate nature that could not be treated or changed, dooming the individual to a life of crime. Permanent incarceration of born criminals seemed necessary to ensure public safety.

8. Cedar Rapids Republican, 1/23/1898.

9. For discussions of biological theories, see Nicole Hahn Rafter, Creating Born Criminals (Urbana and Chicago, 1997), 73-109; Thomas G. Blomberg and Karol Lucken, American Penology: A History of Control (New York, 2000), 68-70; and Platt, The Child Savers, 15-45. See also Koons, "Wesley Elkins." 
Both images are reflected in the controversy over whether John Wesley Elkins should be pardoned. Was Elkins a born degenerate, beyond the hope of redemption and destined to reproduce his own kind? Or could his acts as a child be explained by his young age and the sad circumstances of his upbringing, with his transformation justifying the promise of education and reform? From his prison cell at Anamosa, Wesley Elkins knew that the answers to those questions would determine his fate.

ELEVEN-YEAR-OLD WESLEY ELKINS was not, at first, a suspect in the murders of John and Hattie Elkins, which occurred before sunrise on Wednesday, July 17, 1889, in the quiet farming community of Elk Township in northeast Iowa. ${ }^{10}$ The victims had been married for seven years: John Elkins was a 45-year-old sawmill operator and Civil War veteran, and Hattie, age 23, was his third wife. They shared a small three-room house with two children: Wesley Elkins, the young son of John and his second wife, Matilda, now deceased; and a baby girl, the daughter of John and Hattie. The house was located in an isolated spot in a heavily wooded area, nearly a half-mile from the public highway and just as far from any other residence. Neighbors had not heard a disturbance during the night, but early Wednesday morning, a man living nearby had spotted Wesley, his face and clothes spattered with blood, driving a buggy on the road away from his house with the baby lying on the seat beside him. When the boy was stopped, he volunteered the news that his parents had been killed in the night by an intruder: his father shot and his stepmother "pounded to death." ${ }^{11}$

10. Facts in the text about Wesley's early life, the murders, the inquest, and the investigation are taken primarily from the Elkader Register, 7/18/1889 (the first detailed report of the murders) and 1/16/1890; Cedar Rapids Sunday Republican, 1/23/1898; Des Moines Daily Leader, 3/19/1902; Transcript of Testimony at the Coroner's Inquest on July 17, 1889; and Transcript of Testimony at the Grand Jury Hearing in October 1889. The two transcripts, other legal documents, and many other primary source materials related to Elkins's case are in Elkins folders in the Governor's Correspondence on Criminal Matters at the State Historical Society of Iowa, Des Moines (hereafter cited as Elkins Archives).

11. Elkader Register, 1/16/1890. 
The sheriff found the victims in their bedroom: John Elkins was slain in his bed, struck by a single bullet fired into his left eye and then beaten with a blunt object on the temple and forehead. Hattie, lying next to her husband, had also been violently assaulted; her skull was crushed, her jawbone broken, and the backs of her legs bruised from repeated blows. Neighbors came to view the hideous tableau through the open window before the bodies were removed, and they could see blood splattered on the walls and the ceilings and pooled in the bedclothes and on the floor. A bloody track of footprints - small and barefoot - marked a path from the corpses to the second bedroom, and bedding in that room was also stained with blood. In the words of a reporter, the "horrible" scene inside the house "tried the nerves of the strongest." ${ }^{12}$

The coroner convened an inquest, calling Wesley as the first witness. Under oath, the boy testified that he had eaten supper with his family on Tuesday evening and gone to sleep in the barn, which was cooler than the house. He was wakened by the noise of a gunshot, followed by a woman's scream. He said he was afraid at first, but, when all was quiet, he went to investigate and discovered the bodies on the bed. Although he did not touch them, he thought right away that they were dead. Then he heard the baby, lying on the sheet near her mother's head, "crying bad, as hard as it could." He carried her to the other room, changed her out of her blood-soaked clothes, and took her with him to hitch the horse to the buggy and go for help. ${ }^{13}$

The inquest jury questioned ten neighbors, but none of them knew anything about what had happened during the night. While they could not suggest a motive or a suspect, they did have some information to share about Wesley Elkins. People in the neighborhood did not know the boy well, although they were familiar with the scandalous story of his past. The marriage of his parents - John Elkins and Matilda Blackwell — had ended in dramatic fashion. Said to be a willful and passionate woman, Matilda had taken a lover, entering into a "life of shame" while still married to John. She was pregnant with Wesley when

12. Elkader Register, $7 / 18 / 1889$.

13. Testimony of Wesley Elkins, Transcript of Coroner's Inquest. 
she made several attempts to murder her husband: first, she tried to poison him, then she lay in wait with a loaded gun, and finally, with the help of her paramour, she positioned logs to fall on him while he worked. When all of her efforts failed, she deserted John Elkins, filed for divorce, and then eloped with her lover to Waterloo. Wesley was born there, and he lived with his mother and her new husband for the first seven years of his life, until his mother died and his stepfather sent him away. The 7year-old traveled alone to Clayton County. When he appeared unexpectedly at the small farmhouse where John Elkins lived with his third wife, Hattie, and their baby, the father set eyes on his son for the first time. ${ }^{14}$

Given the history, neighbors were not surprised that John and Hattie Elkins had not welcomed Wesley. Hattie was known to be overbearing, and John quick-tempered and strict, and people suspected that they treated Wesley harshly. At first, Wesley attended school, where teachers found him to be bright and studious, but when he turned 9, his father put him to work during the days tending the fire under the boiler at the mill. ${ }^{15}$ Just a few weeks before the murders, a new rumor had circulated about Wesley: that he had run to a neighbor's house and begged for a ride to Waterloo. According to the story, John Elkins had come after his son and angrily taken him home. ${ }^{16}$

The verdict of the inquest jury stated how the two victims had died but did not identify a suspect. The sheriff, claiming to be mystified by the case, hired a detective from the Pinkerton Agency in Chicago to help search for clues. At the request of county leaders, the governor offered a $\$ 500$ reward for information leading to an arrest. ${ }^{17}$

14. Cedar Rapids Sunday Republican, 1/23/1898; Des Moines Daily Leader, 3/19/ 1902; Koons, "Wesley Elkins."

15. A. B. Curran to Governor Leslie M. Shaw, 1/29/1898, Elkins Archives; A. B. Curran to Senate Committee on Pardons, 2/25/1902, Elkins Archives.

16. Testimonies of Alfred Heath and Wesley Elkins, Transcript of Coroner's Inquest.

17. Transcript of the Coroner's Inquest; Affidavit of Sheriff J. J. Kann, 5/17/1890, Elkins Archives; Robert Quigley to Governor Leslie M. Shaw, 2/2/1898, Elkins Archives; Elkader Register, 7/25/1889; Robert Quigley et al. to Governor William Larrabee, 7/18/1889, Elkins Archives. 
Wesley moved to the home of relatives nearby, and when he returned for the funerals, neighbors commented that he seemed strange: unaffected and indifferent, displaying no sorrow or emotion. Some thought that he might be hiding something, but few supposed that a child, so small and immature, could have committed such violent crimes. ${ }^{18}$

Five days after the murders, the sheriff brought Wesley to live with him and his family, hoping to shield the boy from the public. He also engaged him in private conversations. Before long Wesley confessed to the murders, repeating his statements to a judge. When his confession was reported in the newspapers, Clayton County citizens expressed shock and then outrage at the news. ${ }^{19}$

While many had suspected his involvement, they expected Wesley to implicate an adult. Instead, he said that he had acted alone, planning the killings in advance and even hiding the wooden club he intended to use as a weapon. He described the attacks in detail: he waited until his parents were asleep, then loaded the rifle and retrieved the club, shooting his father in bed and then hitting his stepmother again and again. "I struck her several times more until I was sure she was dead, and then father kind of groaned so I struck him once or twice to be sure that he was dead." As for a motive, Wesley said only that he was tired of doing chores and wanted "to be at liberty to do for myself." When asked why he had not killed the baby, he replied that he liked her. And why didn't he run away after the murders? He didn't want people to think he had done it. According to those who heard him, he was "perfectly cool and self-possessed with no tremor in his voice." ${ }^{20}$

The idea of a child acting in this methodical and brutal fashion was almost beyond comprehension. As the community sought to make sense of the crime, the only reasonable explanation seemed to be that the boy must be an aberration, with an unnatural disposition inherited from his depraved mother.

18. Cedar Rapids Republican, 1/23/1898.

19. Dubuque Daily Times, 7/28/1889; Elkader Register, 8/1/1889.

20. Elkader Register, 1/16/1890 (quoting from the confession); Testimonies of James E. Cortlett and L. O. Hatch, Transcript of Grand Jury Hearing. 
After all, Wesley was in her womb when she tried to murder John Elkins, the very man Wesley now admitted killing. ${ }^{21}$

Wesley Elkins was publicly condemned as a degenerate, "utterly devoid of all moral sense." After talking to the boy, the prosecutor concluded that he "would be a dangerous element in society at any stage of life," and the lawyer appointed to defend Elkins did not disagree. When the boy was indicted by the grand jury on two counts of murder in the first degree, a crime requiring premeditation and criminal intent, his lawyer advised that he plead guilty to one count: the murder of his father. Precedent under common law would have justified a defense on Elkins's behalf arguing that an 11-year-old child was not capable of forming the requisite criminal intent, but the lawyer defending Elkins did not make that claim. Although the prosecutor believed that Elkins's crime warranted the death penalty, he understood that the defendant's age would trigger controversy, so that permanent incarceration was the best alternative. ${ }^{22}$

In early January 1890, Wesley Elkins was sentenced to prison for life. In its report, the local newspaper informed readers that Elkins, utterly lacking in emotion or conscience, was "undoubtedly the youngest ever convicted of such a crime in the criminal history of the United States." Next to his full confession, it printed a recent photograph: with his hair neatly combed and dressed in a suit jacket and polka-dotted bow tie, the boy gazed seriously into the camera, looking like a gentle young schoolchild. ${ }^{23}$ In the years to come, residents of Clayton County would remember the underlying message: that his normal appearance belied his unnatural and uncontrollable criminal nature.

WESLEY ELKINS was age 12 on January 14, 1890, when he entered the State Penitentiary at Anamosa. He was assigned convict number 1900, and his attributes were recorded: occupa-

21. Des Moines Daily Leader, 3/19/1902.

22. Elkader Register, 1/16/1890; Robert Quigley to Governor Leslie M. Shaw, 2/2/1898, Elkins Archives; Cedar Rapids Republican, 1/23/1898. More generally, see A. W. G. Kean, "The History of the Criminal Liability of Children," 53 Law Q. Rev. 364 (1937); and Platt, The Child Savers, 193-212.

23. Elkader Register, 1/16/1890. 


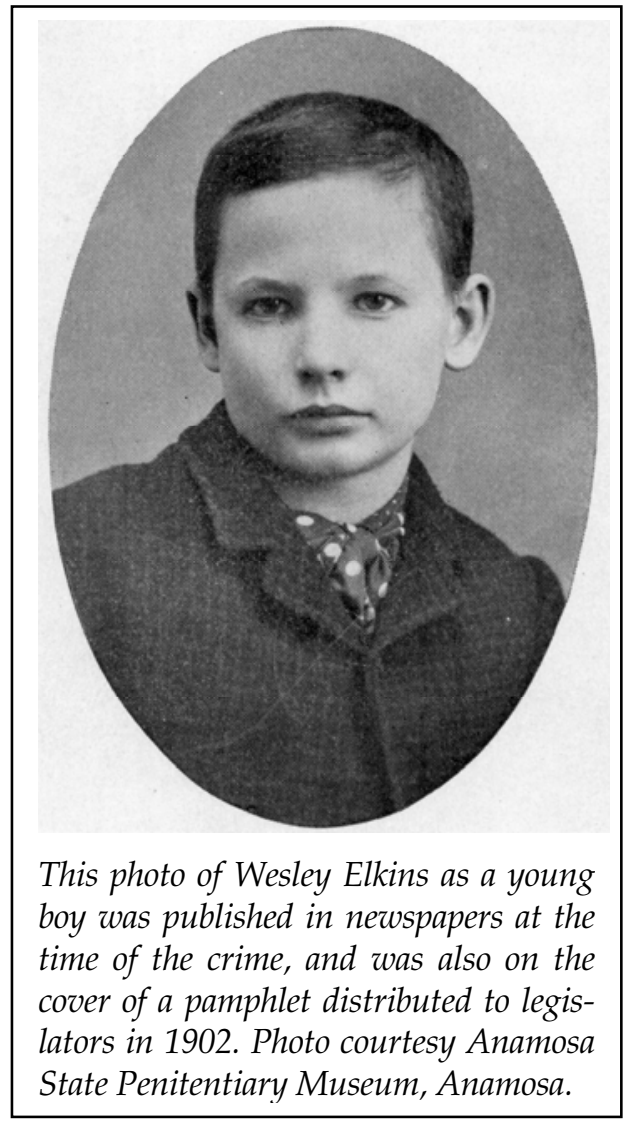

tion, "farmer"; social status, "single"; mental culture, "poor." He weighed 76 pounds, stood 4' 7" tall, and wore a size 4 boot. A few weeks later, a reporter for the Anamosa Journal described "the little fellow," noting that "the unusual breadth of the head between the ears ... would signify an abnormal development of the part of the cranium where the phrenologists say the impulse to do murder has its origin." The reporter did not put much stock in that conclusion, calling it "more humbug than anything else." Instead, he stressed the boy's positive attributes: his "winning" smile, the "truthful light in his dark blue eyes," the facial features that indicated "intelligence, energy and amiability." ${ }^{24}$

24. State Penitentiary at Anamosa, Record of Convicts, State Historical Society of Iowa, Des Moines; Anamosa Journal, 2/13/1890. 
By 1890, the State Penitentiary at Anamosa, in operation for nearly 20 years, was well established, with a population of close to 300. Built to reduce overcrowding at the state prison in Fort Madison, the "Additional Penitentiary," as it was first called, opened in 1873 during a time of significant transition in penal philosophies. ${ }^{25}$ Three years earlier, reformers, educators, and prison administrators had gathered at a national conference and enthusiastically endorsed rehabilitation as the primary goal of incarceration. The resulting Declaration of Principles urged radical institutional changes - stressing individualized diagnosis and treatment - and prisons throughout the country were experimenting with new strategies. ${ }^{26}$

The idea of rehabilitation represented a radical shift in penal philosophy, as commentators rejected the traditional justifications of deterrence and retribution and questioned the effectiveness of harsh discipline, strict routine, isolation, and surveillance. Social observers and journalists were calling attention to environmental causes of crime - poverty, poor living conditions, unemployment - and psychologists were considering the influence of such factors on mental development. A new class of prison administrators emerged, eager to establish themselves as professionals with unique expertise, distinct from the political appointees of the past. Supported by liberal reformers and educators, these officials took the lead in advocating dramatic institutional changes consistent with the new theories. They embraced the goal of rehabilitation, recommending that prisons be designed to focus on the diagnosis and treatment of each individual offender, rather than simply exacting punishment. ${ }^{27}$

25. Joyce McKay, "Reforming Prisoners and Prisons: Iowa's State Prisons The First Hundred Years," Annals of Iowa 60 (2001), 140, 147.

26. Rafter, Creating Born Criminals, 96-103; Blake McKelvey, American Prisons: A History of Good Intentions (Montclair, NJ, 1977), 88-115.

27. For discussions of the changing penal philosophies and the rise of the reformatory movement, see McKelvey, American Prisons, 88-115, 176-89; Blomberg and Lucken, American Penology, 47-81, 100-101; Rafter, Creating Born Criminals; Alexander W. Pisciotta, Benevolent Repression: Social Control and the American Reformatory-Prison Movement (New York, 1994), 7-32; Platt, The Child Savers, 18-45. An excellent description of these changes in Iowa is in McKay, "Reforming Prisoners and Prisons," 139-73. 
During the late nineteenth century, prisons throughout the country experimented with innovative techniques. Progressive wardens replaced punitive methods intended to force compliance with therapeutic measures aimed at transforming those in their charge. Education and vocational training were seen as essential to success, offering opportunities for individual growth and measurable advancement. New grading systems encouraged obedience and industry, with the higher grades rewarded with better food, later bedtimes, and more comfortable uniforms. Freedom, of course, was the ultimate reward, and some penologists advocated indefinite sentencing - with release dependent upon proof of full rehabilitation - as the most effective way to promote moral progress. That idea proved too radical for many, but indeterminate sentences, carrying a maximum term with the possibility of early release, became popular. ${ }^{28}$

The push for indefinite sentences suggested the underlying belief that rehabilitation was not always possible. Even the most ardent prison reformers admitted that certain offenders seemed bent on a path of misconduct and insubordination and were unable to progress through the steps indicating advance. Administrators labeled such inmates as "incorrigibles," often citing biological theories of crime to explain such cases.

At the time Elkins arrived at the Anamosa Penitentiary, many of the rules there still followed tradition. Solitary confinement and corporal punishments continued until close to the end of the century, with prisoners often forced to walk in lockstep and eat and work in silence, although these disciplinary measures were increasingly accompanied by efforts to encourage psychological and social improvement. Prisoners were offered incentives for good behavior, earning credits toward privileges and reduced time, and chaplains took on increased responsibility for moral instruction. Educational programs were put in place; illiterates were required to attend, and many others voluntarily enrolled in courses in literature, mathematics, geography, and history. The prison library expanded its collection,

28. See note 27. For a discussion of the evolution of parole during this period, see Jonathan Simon, Poor Discipline: Parole and the Social Control of the Underclass, 1890-1900 (Chicago, 1993). 
and publicized the value of reading books. ${ }^{29}$ A new prison press began to publish weekly issues, with articles on religious, academic, and political topics, and essays by inmates urging specific penal reforms. ${ }^{30}$ By the end of the century, Anamosa had implemented a grading system, and many administrators actively supported indeterminate sentencing, making an early release dependent upon their judgment of a prisoner's moral progress. $^{31}$

When Elkins arrived at Anamosa, he was escorted to the office of the head warden, Marquis Barr, who was astonished to see the newcomer: he looked small and frail, with delicate features and a "girlish manner." As Barr wrote later, "my heart was filled with pity and sympathy for him." Although there was no formal rule about juveniles, Barr determined that the boy should be separated from older inmates as much as possible. He assigned chores to Elkins and kept him under close personal supervision. The boy seemed fearful and nervous, suggesting to Barr that he had been neglected and abused. After Warden Barr talked to the boy several times, it also seemed clear to him that Elkins was too young to understand the enormity of what he had done. ${ }^{32}$

Warden Barr was convinced, as were other prison officials at the time, that most offenders could be cured with education and proper training, and he took his role in that mission seriously. In his mind, prison officials were responsible for treating individuals in their charge, providing each one with the necessary guidance to achieve reform. Barr accepted that some were not susceptible to change, but his conversations with Elkins convinced him that the boy was not of the "incorrigible" type.

29. See McKay, "Reforming Prisoners and Prisons."

30. The new prison press, started in 1898, is described in Dubuque Herald, 8/7/ 1898.

31. Iowa finally adopted indeterminate sentencing and created a parole board in 1907. See McKay, "Reforming Prisoners and Prisons," 201. See also Fred E. Haynes, The Iowa Prison System (Iowa City, 1954), 29, 59-64 (discussing reduction of sentences for good behavior, paroles, and indeterminate sentences).

32. Mt. Vernon Hawkeye, 2/5/1897; Cedar Rapids Sunday Republican, 1/23/1898; Marquis Barr To Whom It May Concern, 4/17/1897, Elkins Archives. 
Given his youth and stage of development, Elkins seemed a promising candidate for full rehabilitation. ${ }^{33}$

Warden Barr asked the chaplain to pay special attention to the young prisoner, and the two men spent many hours talking to the boy. Barr tried to impress upon Elkins the magnitude of his crimes and the severity of the consequences, but he also sought to encourage him. He advised Elkins to strive for obedience, educational progress, and moral understanding, assuring him that, if successful, he would be rewarded with eventual release. As Barr wrote later, "society cannot afford to punish for revenge," and so "must be willing to quit when it is evident that further punishment can do no more good." Elkins would have to show that he was not a threat to society, that he knew the difference between right and wrong, and that he "would choose to do right because it is right." ${ }^{\prime 34}$

When Barr left Anamosa in 1892, he was pleased by Elkins's good record of behavior and moral growth. The new warden, Philander Madden, shared Barr's belief in the promise of rehabilitation, and he, too, paid special attention to Elkins. Madden agreed that Elkins should be isolated as much as possible from older inmates, and so he assigned him to duty in the prison library, where he would be close to the chapel and the schoolroom. ${ }^{35}$

The job in the library proved a perfect fit for Elkins. As Warden Madden later recollected, Elkins "speedily developed a deep love for the books with which he was surrounded, and every moment of his time not occupied with his duties as librarian was dedicated to the close perusal of such works as he was then able to master intelligently. Encouraged and assisted by the prison chaplain and others, his progress in this connection was nothing less than phenomenal." Elkins became a serious student, reading widely from the collection, and favoring classic works of literature and philosophy. He impressed prison officials with his eagerness and quick ability to learn, traits that were remarkable to his supporters in later years. ${ }^{36}$

33. Marquis Barr To Whom It May Concern, 4/17/1897, Elkins Archives.

34. Cedar Rapids Sunday Republican, 1/23/1898.

35. Ibid.

36. P. W. Madden To Whom It May Concern, 1/25/1898, Elkins Archives. 
In the fall of 1892, when he was 15, Elkins found a published decision from the Iowa Supreme Court that seemed particularly relevant to his case. The decision quoted a jury instruction stating the common-law rule that a child between the ages of 7 and 14 is presumed to be incapable of committing a crime. Given the presumption, a child may be convicted of a crime only if the state proves by evidence that the defendant has sufficient capacity to comprehend what he had done. Without such proof, the child must be acquitted. In the particular case on appeal, the state claimed that the defendant was older than 14, making the instruction irrelevant, but both sides conceded that it was an accurate statement of the law. ${ }^{37}$

The opinion, dated 1879, suggested that the common law was established well before Wesley Elkins pled guilty to the murder of his father. Elkins took the case directly to Warden Madden and asked for a lawyer to investigate his right to a writ of habeas corpus. ${ }^{38}$ Legal counsel was not provided, but Elkins did not forget the clear suggestion that his fate was illegal and unjust. $^{39}$

WESLEY ELKINS soon learned that he had only one path to freedom. Under the Iowa Constitution, the governor had the exclusive power to pardon a convict and to commute a criminal sentence, although his power was limited in the case of an individual guilty of first-degree murder. The governor could deny the request on his own volition, but he was authorized to grant such a pardon only after seeking advice from the General Assembly. The law also required that the public be notified of an upcoming review by the legislature, so that interested parties could make their views known. Notices were to be published for four consecutive weeks in two different newspapers - one in Des Moines and one in the county where the trial had been

37. P. W. Madden to Governor Horace Boies, 10/27/1892, Elkins Archives; State v. Fowler, 52 Iowa 103, 2 N.W. 983 (1879).

38. P. W. Madden to Governor Horace Boies, 10/27/1892, Elkins Archives.

39. In subsequent years, lawyers opined that a writ of habeas corpus, if it had been filed within the proper time, would have secured Elkins's release from prison. Davenport Republican, 4/6/1902. 
held - with the final one appearing at least 20 days prior to the commencement of the General Assembly. ${ }^{40}$

The Iowa General Assembly convened only once every two years. Its session began in early January of even-numbered years, just as the newly elected governor was inaugurated for his twoyear term. To allow time for public notice before legislative review, convicted murderers filed their applications for pardon in mid-November of odd-numbered years. History showed that they did not have much chance of success. The law had been enacted in 1872; by 1895, only 11 convicted murderers had been released from prison, representing a small percentage of those who had applied. ${ }^{41}$ The number might have been higher if the possibility of parole had been considered, but the law did not contain a specific provision allowing for conditional release of life prisoners. Governor Leslie Shaw broke with tradition for the first time in 1900, when he authorized a life prisoner to be released for a probationary period, with a subsequent pardon dependent upon his compliance with specific terms. ${ }^{42}$ Until then, the choice was considered to be between continued incarceration and unconditional pardon.

In late November 1895 Elkins filed his first request for pardon, along with nine other convicted murderers. At 18, he was by far the youngest of the group. He cited two grounds to justify his appeal: his age when he committed the crime and the sufficiency of the punishment he had already suffered. ${ }^{43}$

Although Elkins addressed his application to Governor Frank Jackson, the governor's term was about to expire, so he would not be the one to make the final decision in the spring. Besieged by other requests for clemency, Governor Jackson decided not to discriminate among those requiring legislative review. He forwarded them all to the General Assembly and arranged for publication of the required notices. ${ }^{44}$

40. Iowa Constitution, article 4 , § 16; Iowa Code $§ 4712$ (1873).

41. Cedar Rapids Weekly Gazette, 4/14/1904.

42. Sioux County Herald, 4/18/1900.

43. Affidavit of Publication from J. R. Clarkson, publisher of Iowa State News, 12/20/1895, Elkins Archives.

44. Cedar Rapids Republican, 11/27/1895. 
By that time, Elkins had come to the attention of Carl Snyder, a well-known journalist and the first of several influential men to advocate on his behalf. Snyder was only 24 years old, but he had been editor-in-chief of the Council Bluffs Nonpareil for four years, and he was respected throughout the state for his sharp intelligence and his confident and persuasive style. ${ }^{45} \mathrm{He}$ had strong views about Elkins's case that he was eager to share with the public.

In a letter to Governor Jackson, Snyder admitted that he had not met the boy in person, but he had corresponded with him and was well aware of his remarkable educational progress. ${ }^{46}$ Snyder had investigated the case and was horrified at the injustice of a child doomed to spend the rest of his life behind bars. As Snyder wrote to the governor, "no sane man" could agree with the "bungling notion that a child can be treated as a felon and a convict." The result seemed absolutely immoral, and Snyder was convinced that it must be wrong as a matter of law. He appealed to the governor to consider the case not just because of Elkins but also because of the appalling precedent the decision, if allowed to stand, would set in the state. ${ }^{47}$

People in Clayton County and its environs may not have heard much about Wesley Elkins in the years since he had been imprisoned, but they had not forgotten John and Hattie Elkins or the bloody havoc wreaked by the boy murderer. They did not take well to the news that someone at such a distance across the state in Council Bluffs - was interfering in the legal consequences imposed by their judge for a crime that had occurred in their midst. Clayton County citizens already had reason to feel isolated from other Iowans and resentful at taking direction from outsiders. Located in the northeast corner of Iowa,

45. "Carl Snyder, Pioneer Economic Statistician and Monetarist," History of Political Economy 10 (1978), 455; Council Bluffs Nonpareil, 2/19/1946.

46. Carl Snyder to Governor F. D. Jackson, 11/22/1895, Elkins Archives. Elkins had contacted Snyder first, in response to an editorial of Snyder's advocating that juvenile offenders should be segregated from other prisoners. Des Moines Daily Capital, 4/21/1902.

47. Carl Snyder to Governor F. D. Jackson, 11/22/1895, Elkins Archives. In his letter, Snyder refers to another letter he had written to the Iowa State Register setting forth his views on the Elkins case, but it appears that the Register did not publish it. 
Clayton County was largely rural and agricultural, made up of farms linked to small towns, and without a large metropolitan area. Beginning in the mid-1880s, its heavily German immigrant population contributed to making it one of the few Democratic counties in a state generally controlled by Republicans. Usually in the minority in state government, its representatives, speaking for their constituents, often strongly opposed state policies and directives. Residents of Clayton County, for example, had strongly protested the Republican push to pass prohibition laws, and attempts to enforce those that were enacted generated heated controversy and hostility. ${ }^{48}$ And state laws were a different matter than local crime, which was investigated, tried, and judged by elected county officials. In the minds of many Clayton County citizens, the fate of Wesley Elkins should be up to them to decide.

In early December, the Cedar Rapids Republican reported that "a movement is on foot" to secure a pardon for Elkins - one of the most infamous criminals in the state - who had gained the support of the "brilliant newspaper correspondent" Carl Snyder. ${ }^{49}$ According to the newspaper, Clayton County was convinced that Snyder, acquainted with the boy only from his letters and at a distance, was sadly misinformed, and his sympathy misplaced. Those who knew the boy understood his true nature: he was a "fiend ... born with murder in his heart," a criminal who "would indulge his murderous propensity on the slightest provocation. ${ }^{\prime 50}$ His inner nature was immune to the cultivating influence of education or anything else, and efforts at rehabilitation were destined to fail. His release would be a terrible mistake with dangerous consequences.

Proof of this conclusion was offered by a man referred to as "one of Clayton County's most distinguished residents" who claimed expertise because "he knew the young criminal well

48. Realto E. Price, History of Clayton County, Iowa: From the Earliest Historical Times Down to the Present (Chicago, 1916), 240-44; Richard Jensen, "Iowa, Wet or Dry? Prohibition and the Fall of the GOP," in Iowa History Reader, ed. Marvin Bergman (Iowa City, 2008), 267-70.

49. Cedar Rapids Republican, 12/1/1895. News of Elkins's application had been reported in the Cedar Rapids Daily Republican a few days earlier $(11 / 28 / 1985)$.

50. Cedar Rapids Republican, 12/1/1895. 
[and] had conversed with him often relative to the crime." Although this individual asked not to be publicly identified as the source, he agreed to a lengthy interview, in which he described incidents that were not part of the record and expressed his strong negative impressions of the boy. Two years later, when the Republican changed its position to support Elkins, the editor identified the earlier anonymous source as the lawyer charged with defending Elkins in 1888, implying that both the additional details he offered and his personal assumptions about Elkins almost certainly came from confidential communications with his young client that should not have been disclosed to the public. ${ }^{51}$

The lawyer recalled the boy's planning and execution of the "diabolical deed," provoked only by a "mild scolding" from his parents, and then his reaction when his lies were discovered: he admitted what he had done in a tone of "supreme indifference, never displaying a single sign of sorrow . . . [or] any human feeling whatever," and "without a shadow of remorse." The lawyer claimed that Elkins had displayed an uncontrollable impulse to violence even before the murders. As a child, he had terrorized his schoolmates, and since he had been at the penitentiary in Anamosa, he had assaulted other prisoners. The editorial closed with a solemn warning against trusting Elkins's show of reform: "It is evident that through some cause - we know not what - this boy is possessed with a passion to kill. He can not . . . be released. He should be treated kindly, educated and given a chance to earn something, but he should not be set at liberty. The chances are too desperate." ${ }^{52}$

Isolated from society since he was a child, Elkins may not have anticipated the monstrous depiction of him or the vehement reactions to his request. He was taken aback by the factual inaccuracies, and he was quick to respond with a five-page handwritten letter addressed to the editor of the Republican. On the advice of prison officials, he sent the letter to the governor rather than to the newspaper, with a brief cover note asking for

51. Cedar Rapids Sunday Republican, 1/23/1898.

52. Cedar Rapids Republican, 12/1/1895. 
the governor's help in correcting errors in fact that would affect legislators in their consideration of his case. ${ }^{53}$

Elkins objected to the account of the "anonymous" Clayton County citizen, characterizing it as "one mass of falsehood, from beginning to end, brought out by prejudice and passions with hardly a word of truth in it." Elkins refuted the specific charges said to prove his violent nature, denying reports that he had been feared or avoided by his schoolmates, and that he had ever attacked a fellow prisoner. Prison officials and guards, he said, would confirm his exemplary record. Elkins also disputed that he had struck out against his parents as retribution for a "mild scolding," as stated by the Republican. He offered a different account of his childhood, one he had previously confided to Warden Barr. "If my father and stepmother had treated me in any degree kindly, I would not be behind these walls today. . . . They were cruel in the extreme; many a night I have been sent to bed, with my back so sore from a whipping, that I could not lay on it; ... goaded on by such treatment, which I did not deserve, I committed the rash deed [and I] shall always deplore it to the end of my days. ${ }^{154}$ Elkins asked the newspaper to print a retraction. It did not do so; it neither acknowledged receipt of the letter from Elkins nor admitted any mistakes in its story.

In the spring of 1896, Elkins was notified that his request had been rejected by the House Committee on Pardons. Citing the "meager showing of the facts," the committee recommended that the appeal be "indefinitely postponed without prejudice." Although three lifers were released from prison that spring, Elkins remained behind bars. ${ }^{55}$

EIGHTEEN MONTHS LATER, in the fall of 1897, Elkins filed his second application for pardon with the outgoing governor, Francis Drake. He repeated the grounds from the previous ap-

53. John W. Elkins to the Editor of the Cedar Rapids Republican, 12/2/1895, Elkins Archives; John W. Elkins to Governor Frank D. Jackson, 12/3/1895, Elkins Archives.

54. John W. Elkins to the Editor of the Cedar Rapids Republican, 12/2/1895, Elkins Archives.

55. Journal of the House of Representatives of the Twenty-Sixth General Assembly of the State of Iowa (1896), 773, 914; Cedar Rapids Weekly Gazette, 4/14/1902. 
peal: his age and the punishment already imposed. This time, he also expressed "bitter regret" and noted his good conduct record and educational progress as proof that he was "fitting himself for a better and higher life." ${ }^{156}$ When Governor Drake forwarded the application to the General Assembly, the reaction was dramatically different than two years earlier. Thanks to a new and influential advocate, Elkins's plea garnered widespread support and statewide publicity.

In December 1897 the Anamosa Eureka published a long letter written by Elkins to Carl Snyder. The Eureka had received the letter from Warden Madden, along with a personal note affirming its authenticity. Madden expressed his confidence that Elkins, if released, would pose no threat to the public. He hoped that the letter might attract the attention of someone who could advocate for Elkins in the General Assembly.

When the Eureka published Elkins's letter, it noted the author's "thoughtfulness and grace of expression, as well as beauty of penmanship and correctness of punctuation," especially from a young man who had not enjoyed much formal education as a child. The newspaper added an editorial comment commending the substantive strength of the appeal, and recommending that Elkins be released from prison. ${ }^{5}$

In the letter, Elkins presented a picture of himself that was in stark contrast to images conjured up by his crimes. Despite his unique circumstances, Elkins expressed deep and universal emotions: confusion and sorrow as he looked back on his tragic past; desperate anxiety, fear, and a glimmer of hope as he faced his uncertain future. He did not present a legal argument for pardon, nor did he defend his actions. Instead, he described himself as a boy "who had not yet reached the age of reason" when he had committed his crimes, and who had now been in

56. Wesley Elkins, Application for Pardon to Governor F. M. Drake, 1897, Elkins Archives.

57. Des Moines Daily Capital, 4/21/1902. To the warden, it seemed an especially good time to release rehabilitated inmates. Economic hardship in the state had caused an increase in crime, and Anamosa was dangerously overcrowded. The population had more than doubled since Madden had assumed his office, and prisoners were sharing cells, with some even forced to camp out in the yard. Cedar Rapids Republican, 1/4/1897; Haynes, The Iowa Prison System, 14-15.

58. Anamosa Eureka, 1/28/1897; reprinted in Mt. Vernon Hawkeye, 2/5/1897. 
prison as long as was "necessary for the benefit of good morals." He told of his constant efforts to arm himself for the future by "hard study" and by cultivating self-reliance, even while facing the prospect of lifelong incarceration, and wondering "how much strain will my mind stand before I shall become a physical and mental degenerate?" ${ }^{\prime 59}$ His determination and his sincere expressions of anguish earned him the sympathy of many readers.

When the letter was reprinted in the Mt. Vernon Hawkeye, it caught the eye of Professor James Harlan of Cornell College. In 1897 Harlan was 52 years old and at the midpoint of his career. He had graduated from Cornell in 1869, married a college classmate the same year, and then, after a four-year stint as public school superintendent in Cedar Rapids, returned to Cornell as the first alumni professor. Harlan taught courses in mathematics and astronomy, but he was also fascinated by the fields of psychology and ethics. In 1881 he was appointed to the newly created position of vice president of the college, an office he was to hold for 27 years until he assumed the presidency in $1908 .{ }^{60}$

Reserved and modest in manner, Harlan was cautious in making decisions. According to a colleague, his approach "revealed that fine balance of intellect that is characteristic of the true scientist, weighing both sides of the question carefully and then coming to a conclusion only after marshalling all the facts involved." As the college's top disciplinary authority, Harlan had developed an absorbing interest in the moral and spiritual development of young people. Without children of his own, he focused on his influence over youth in the wider community. ${ }^{61}$

Professor Harlan knew Elkins's story and realized that, at age 20, he was now just the age of many of his students. Harlan was deeply impressed by Elkins's determination and expressiveness. As a teacher of psychology, Harlan was also fascinated on an abstract level, considering what the case suggested about mental and moral growth, and about how an individual might be

59. Ibid.

60. Mt. Vernon Hawkeye, 12/28/1929; H. J. Burgstahler, “James Elliott Harlan, 1845-1933," Cornell College Bulletin 35, no. 8 (1934); Des Moines Daily Capital, 4/21/1902. This James Harlan should not be confused with the Iowa legislator who played a dominant role in state and national politics until the mid-1870s.

61. Burgstahler, “James Elliott Harlan.” 
affected by education, environmental conditions, and example. In his typical methodical fashion, Harlan began to solicit information and investigate the facts.

Clayton County residents shared their views of Elkins as a born murderer, not susceptible to reform. A lawyer from the area quoted from the boy's confession, describing how he had planned and carried out the crimes. The lawyer remembered the boy's lack of emotion or remorse, and related the widely accepted theory that Elkins had inherited his "murderous disposition" from his mother. A local minister also wrote to oppose Elkins's release, describing the boy as "coldly cruelly maliciously vindictive"; his permanent incarceration was the only way to protect the public safety. "We have had enough 'degenerates' loose in the country, murdering by the wholesale. Society is to be considered as well as the individual." ${ }^{62}$

Professor Harlan knew that many criminologists doubted that heredity led to immutable criminal dispositions. They emphasized instead the significant influences of outside forces during maturation. Harlan was also encouraged by the reports he received about Elkins from those at Anamosa. In a letter to Harlan, former Warden Barr described Elkins's childish appearance when he first arrived, and his own conclusions: that Elkins had been driven to commit his crimes by mistreatment from his parents, and that he was too young at the time to understand what he had done. Barr and the other wardens who knew Elkins spoke in the most positive terms about his development since then, noting his educational advancement and excellent behavior and denying any show of violence on his part. To prison officials, Wesley Elkins was an exemplar of institutional success, and he deserved his chance at freedom. ${ }^{63}$

When Harlan visited Elkins, he was impressed by his intelligence; he seemed "possessed of really brilliant mental equipment." ${ }^{\prime 4}$ Initially intrigued by the theoretical issues, Harlan gradually developed a more personal and paternal bond with Elkins. Early in 1898, Harlan decided to work toward Elkins's

62. Cedar Rapids Republican, 1/23/1898.

63. Ibid.; P. W. Madden To Whom It May Concern, 1/25/1898, Elkins Archives. 64. Des Moines Daily News, 2/24/1898. 
release, and he remained one of his strongest advocates for years to come. Elkins, for his part, recognized and appreciated Harlan's empathy and support, and overcame his natural reticence, allowing a "frank and open exchange."

In mid-December 1897 the Iowa State Register and the Elkader Argus published notices that Elkins was applying for a pardon. ${ }^{66}$ Just as they had two years earlier, many Clayton County residents reacted to the news with great hostility. Petitions opposing Elkins's pardon circulated throughout Clayton and adjoining counties, gathering more than 1,300 signatures by the time they were presented to the legislature later that spring.

Hiram C. Bishop, the editor and publisher of the Clayton County Democrat, was especially outspoken in his objections. A longtime resident of the county, Bishop had served as its school superintendent for seven years before starting the Democrat in 1893. He claimed to remember Elkins as "an unusually bright and attractive lad . . . but if you looked closely you could see a peculiar expression in his steel-like eyes" indicating that he was "born with murder in his heart." Known as a man of strong convictions and vigorous personality, Bishop was also politically ambitious. Active in the Democratic Party, and already influential in Clayton County through his newspaper, Bishop was eager to prove that his voice could be heard throughout the state. ${ }^{68}$

According to an editorial in the Democrat, Elkins had revealed his character by his crimes, "demonstrating beyond a doubt that he possesses a morbid, beastly nature which in all probability he can never overcome this side of the grave." Deformed at birth by "prenatal influence," Elkins displayed "idiosyncrasies [which] may at any moment prompt him in a fit of anger or some fancied wrong to slay his fellow man." The citizens of Clayton County knew firsthand about the boy's uncontrollable "carnal nature," and, since it was their safety that

65. Cedar Rapids Republican, 1/23/1898.

66. Affidavit of Publication from J. R. Clarkson, publisher of the Iowa State Register, 12/13/1897, Elkins Archives; Affidavit of Publication from Herbert Cook, publisher of the Elkader Argus, 1/20/1898, Elkins Archives.

67. Fredericksburg News, 3/3/1898; Semi-Weekly Iowa State Reporter, 2/25/1898.

68. Des Moines Daily Capital, 1/15/1902; Price, History of Clayton County, 48-50; Elkader Register, 3/24/1921. 
would be endangered by his release, they should be the ones to decide. The Cedar Rapids Republican echoed these views, repeating the conclusion that Elkins was a dangerous degenerate who would not hesitate to murder again. ${ }^{69}$

Less than two weeks later, though, the Republican publicized a much different image of Elkins, devoting its entire front page, seven columns across, to the case. The Republican's editor, William Boyd, explained his renewed interest in the case: Soon after endorsing the opposition to Elkins's release, Boyd was contacted by James Harlan, someone he respected as a leading educator, who suggested that Boyd had reached his conclusions without sufficient research. Harlan asked Boyd to study the data from his investigation and travel with him to Anamosa to meet Elkins. ${ }^{70}$

The bold headline in the Republican asked the question "Shall Wesley Elkins Be Granted a Pardon?" In slightly smaller type, the paper suggested the answer: "Earnest Students of the Remarkable Case Have Concluded that Society Will Not be Endangered If the Pardon Prayed For be Granted." ${ }^{71}$ The newspaper printed arguments on both sides of the question, but the editor had clearly decided to support Elkins.

Letters from Clayton County described the crime and shared the theory that Elkins was destined to continue his criminal conduct. Statements from the wardens at Anamosa expressed their disagreement, describing the young man they knew and conveying their confidence in his complete rehabilitation.

Most of the text on the front page, though, consisted of writings by Elkins; four of his letters, including one to Harlan and one to the General Assembly, were printed in their entirety. The Republican editor knew that some readers might doubt whether Elkins, with little formal schooling, could be the author, given the perfect punctuation, elegant diction, and fine analysis, which "would do credit to a trained lawyer." But Boyd, having watched the young man compose a letter with the same handwriting and exceptional style as the others, assured his readers that the letters were authentic.

69. Clayton County Democrat, 1/11/1898; Cedar Rapids Republican, 1/15/1898.

70. William R. Boyd, “James Elliott Harlan, 1845-1933," Cornell College Bulletin 35, no. 8 (1934).

71. Cedar Rapids Republican, 1/23/1898. 
Elkins made his case with eloquence. Although he did not rely on legal precedent, he noted his young age at the time of the crimes and his inability to comprehend the consequences. He wrote of his remorse and sorrow, adding that "words cannot express the regret I feel." He then described his devotion to his education and moral progress since he had been at Anamosa. His appeal to the legislature was personal and emotional:

In the long years I have spent in this prison I have stood alone. I have carried a weight of prejudice that at times was almost too heavy to bear, yet notwithstanding all this I was buoyed up by hope. I felt that the time would come when justice would impel men to set aside the sentence in my case. With hope of liberty as an incentive I have struggled alone and unaided to develop and cultivate my mind so as to fit myself to fill the position of a man among men....

My purpose is to appeal to your reason and sense of justice, avoiding sentiment....

I committed a terrible crime, that I know, but has not my punishment been severe - to spend my boyhood behind prison walls? ... Could you take enough interest in me to look up my case, and examine my prison record, and if you are satisfied, set aside the sentence in my case? You will not regret your kindness to a boy who finds himself almost alone in the world, with a fate worse than death staring him in the face.

I cannot tell you what it would mean to me. It was so long ago that I came here I can hardly remember what it was to be free. . . I I have never known what it was to be a boy like other boys. Now I am a young man, determined to make a success in life; and I am sure if you have confidence in me I will not abuse it.

I ask you to think what it means to grow up in a prison, to feel that you might be out in the world making your own way - or, at least, to struggle to do your best - and then realize that you are shut up here - for life! Sometimes, thinking about it, I feel as if I would go mad. I do not believe any one else can understand what it means.

I make this appeal to your sense of justice. I appeal to your humanity to give me another chance to begin anew my unhappy life. Will you help me? ${ }^{72}$

72. Cedar Rapids Republican, 1/23/1898. 
The Republican added a final comment after this letter from Elkins in support of his release. The note acknowledged that some believed that a child could be "cursed before his birth," and so doomed by his heredity to a life of crime. But the alternative theory seemed more likely, with character viewed as less immutable and moral consciousness a product of environmental and social influences. Thus, even a child subject to negative prenatal influences and who had done wrong at an early age could develop in a positive direction under the right conditions, learning self-control and abiding by moral principles. Elkins seemed a case in point, and so, according to the Republican, he now deserved an opportunity to prove that he deserved his freedom. The Republican offered a novel idea to ease the fear that he might be a threat: His release could be conditional at first, requiring that he remain under the guardianship of a responsible person. Misconduct would mean his return to prison, while satisfactory completion of the probationary period would end with a full and complete pardon.

The Republican's views did not convince those in Clayton County. The county's senior senator, John Everall, a longtime resident and leading member of the Democratic Party, took the lead in opposing Elkins's pardon. Pledging to fight to keep him in prison, Everall distributed strongly worded letters and petitions from his constituents and, according to one report, did all he could "to arouse the feelings of the legislators against the criminal." ${ }^{74}$

Professor Harlan was the strongest advocate for Elkins's pardon, with his emphasis always on proof of rehabilitation. He continued to solicit testimonials from Anamosa, and he traveled to Des Moines to talk to legislative committees, promising that

73. Cedar Rapids Republican, 1/23/1898. In the past, life prisoners had been granted unconditional pardons if their applications were approved. The terms suggested by the newspaper for Wesley Elkins were followed closely when Governor Shaw issued the first parole to a life prisoner in 1900. See Sioux County Herald, April 18, 1900. The idea of probation for a convicted murderer was in contrast to a recommendation from the Republican two years earlier: that all those convicted of first-degree murder should be put to death, and that no one sentenced to life in prison should be pardoned unless there was clear doubt as to the defendant's guilt in the case. Cedar Rapids Republican, 4/26/1896.

74. Cedar Rapids Republican, 2/5/1898. 
he would make it possible for Elkins, if released, to continue his education. In the words of one newspaper, Harlan's efforts, "so evidently prompted by the highest motives and made after the most thorough investigation, have proved a tower of strength to the Elkins case." ${ }^{75}$

At Anamosa, Elkins received a steady stream of visitors throughout the spring. Members of the house and senate pardon committees interviewed him, and other legislators traveled to the prison on their own. Two ministers from Clayton County, initially against the pardon, changed their opinions after their trip to Anamosa: If Elkins could be placed with some trustworthy man, they would no longer oppose his release. After a twohour interview, Senator Everall also admitted that his feelings had softened somewhat. If, at some point in the future, he could be convinced that Elkins was not a danger to others, he was "quite ready to be charitable."

Sentiment among legislators was evenly divided. Supporters expressed optimism, but they were concerned that a defeat would prejudice Elkins's chances in the future. Senator William Mitchell, a friend of Harlan's, proposed a solution that he hoped would satisfy both sides. In deference to the strong opposition, the petition would be withdrawn for now, but it would be considered again in two years by the next General Assembly. At that time, Senator Everall and the people of Clayton County would not fight it. Senator Everall could not guarantee the support of his constituents, but he thought the suggestion made sense. In late March, the Cedar Rapids Republican reported that the petition had been withdrawn and that legislators had "tacitly agreed" to recommend Elkins for pardon in 1900. That story was followed by a final letter from Elkins addressed to the legislature, expressing his appreciation for all efforts on his behalf and his great hope of entering college in the future so as to "lay the foundation for a true and industrious manhood." ${ }^{\prime 77}$

75. Des Moines Daily News, 2/24/1898; Cedar Rapids Republican, 2/27/1898.

76. Anamosa Eureka, 2/10/1898; Cedar Rapids Republican, 2/20/1898, 2/23/1898, 2/15/1898.

77. W. O. Mitchell to Governor Leslie M. Shaw, 11/24/1899, Elkins Archives; Cedar Rapids Republican, 2/5/1898, 3/23/1898. 
WESLEY ELKINS filed his third request for pardon in November 1899. This one was addressed to Governor Leslie Shaw. ${ }^{78}$ Having maintained his exemplary record of conduct, Elkins had good reason to feel optimistic.

Governor Shaw was about to begin his second two-year term. Although relatively unknown when first elected, having been put forth by conservatives in the Republican Party to ward off a challenge from the more progressive wing, Shaw had earned widespread praise while in office. He was easily reelected in November 1899, with Republicans remaining firmly in control of the legislature. Although relieved by the election results, Governor Shaw knew that he faced a difficult political struggle in January. Six years earlier, Republicans in the General Assembly had elected John Gear as U.S. Senator from Iowa, with Albert Cummins, a leading voice of progressives in the party, as his disappointed opponent. Senator Gear was now elderly and in feeble health - he was too ill to campaign — but conservatives had decided on him for a second six-year term. Cummins's supporters believed that their man was entitled to the post, and they had waged a long and bitter fight on state and local levels through the fall of 1899. The conservatives were to be successful in January, with Senator Gear reelected (only to die five months later), but the split in the Republican Party, exposed so clearly in the last months of 1899, would deepen as the new century began.

Governor Shaw was not anxious to antagonize either side. While indebted to the conservatives, he also appreciated the popular appeal of progressive leaders. And Shaw was an ambitious man, with national aspirations. Many said that he hoped to be Iowa's senator someday, and achieving that goal depended upon broad Republican support. ${ }^{80}$

Shaw was familiar with the facts of Elkins's case. As the new governor in the spring of 1898, he had followed the legislative

78. J. Wesley Elkins to Governor Leslie M. Shaw, 11/11/1899, Elkins Archives.

79. Des Moines Daily Capital, 11/8/1899; Russell B. Nye, Midwestern Progressive Politics: A Historical Study of Its Origins and Development: 1870-1958 (East Lansing, MI, 1959), 210; Cyrenus Cole, A History of the People of Iowa (Cedar Rapids, 1921), 514.

80. Cole, A History of the People of Iowa, 515. 
controversy, realizing that a positive recommendation would put the decision in his hands. Shaw knew that James Harlan was one of Elkins's strongest supporters and that opposition from Clayton County would be intense. Senator Everall would not be in the senate in 1900, but he had been replaced by Hiram C. Bishop one of Elkins's most vehement opponents in the past. ${ }^{81}$

Governor Shaw was close friends with Harlan, who had been a young professor at Cornell when Shaw was a student there. Bishop's ideas, though, seemed more persuasive to Shaw, especially given new scientific and popular writings warning that moral degeneracy would spread, weakening the populace, if those who carried the trait were allowed to reproduce. The risks of releasing Elkins seemed significant. As the county attorney who had prosecuted Elkins in Clayton County wrote to Shaw, freeing Elkins would not only endanger other lives, but it would allow him to "beget more of his kind," spreading his affliction throughout society. ${ }^{82}$

To avoid political conflict, Governor Shaw decided that the General Assembly should not debate Elkins's case. He forwarded four applications from convicted murderers to the General Assembly, but Elkins's was not among them. Shaw wrote directly to Harlan to tell him of his decision. "If the General Assembly were to authorize his pardon, I should be compelled to decline it; and this being true, I ought not to put the state to the expense of an investigation." Shaw expressed his regret at disappointing "one of the best friends I ever had," but the evidence - that Elkins was afflicted with "abnormal proclivities" that "he was incapable of controlling" - seemed too strong for Shaw to ignore, especially given the strong public sentiment against Elkins. ${ }^{83}$

The news distressed Harlan, who traveled to Des Moines to meet with the governor and to remind him that legislators in the previous session had promised Elkins that he would be recommended for pardon. Shaw would not reconsider. Eventually,

81. Senator Everall declined to run for re-election in the fall of 1899. Waterloo Daily Reporter, 8/19/1899; Waterloo Daily Courier, 9/26/1899. Hiram C. Bishop narrowly won the election in November.

82. Robert Quigley to Governor Leslie M. Shaw, 2/2/1898, Elkins Archives.

83. Semi-Weekly Cedar Falls Gazette, 1/9/1900; Leslie M. Shaw to James E. Harlan, 11/23/1899, Elkins Archives. 
Harlan persuaded him to offer some small consolation to Elkins; he agreed to forward a pardon request from Elkins to the Twenty-Ninth General Assembly in January 1902. Shaw did not expect to be in office that spring, so if the legislature approved the request, the final decision would be up to his successor. ${ }^{84}$

POLITICAL UPHEAVAL and social change in Iowa marked the two years that passed before Elkins filed his fourth application for pardon in November 1901. Woman suffrage was a topic of great debate, and many of its strongest proponents were also influential in raising issues about children. The National Congress of Mothers, an organization formed to focus on child welfare, held its annual meeting in Des Moines in 1900, and Iowa members created a state chapter soon after that. From its inception, the group worked hard throughout Iowa to publicize contemporary ideas about the importance of schooling and parental guidance in early development, and to propose new explanations for the serious problem of juvenile crime, emphasizing circumstances such as neglect, poverty, and negative influences at home. The notion that children should be treated differently under the law was also gaining strong advocates, with supporters arguing that Iowa should follow the lead of Illinois, which had established the first juvenile court system in 1899. And many supported the establishment of a separate reformatory for youthful criminals in Iowa, believing that children, still at an early stage of development, were most dramatically shaped by their environment and by those around them, and so offered the greatest promise of rehabilitation. ${ }^{85}$

84. James E. Harlan to Governor Leslie M. Shaw, 10/28/1901, Elkins Archives; Governor Leslie M. Shaw to James E. Harlan, 11/23/1899, Elkins Archives.

85. Twenty Years of Work for Child Welfare by National Congress of Mothers and Parent Teacher Associations (Washington, DC, 1917), 20-21. For the history of the juvenile court in Iowa, as well as the role of the National Congress of Mothers, see Hazel Hillis, "Securing the Juvenile Court Law in Iowa," Annals of Iowa 23 (1942), 161-88. Discussions of the theories of juvenile crime that were becoming more accepted at the turn of the century are found in "The Juvenile Offender," Bulletin of Iowa Institutions 4 (1902), 452-60; Platt, The Child Savers, 46-74; and Steven L. Schlossman, Love and the American Delinquent: The Theory and Practice of "Progressive" Juvenile Justice, 1825-1920 (Chicago, 1977), 57-78. 
The increased public attention to children was a favorable trend for Elkins. Arguments stressing the mistreatment he had suffered as a child were consistent with modern thinking. And his transformation into the articulate and intelligent young man who now pleaded for his release seemed to justify the hope that a moral consciousness could be developed under the influences of education and positive adult guidance. ${ }^{86}$

On the other hand, many people continued to hold to the notion of the born criminal. The notion dated back to the early nineteenth century, when scientists in the new field of phrenology suggested that deformities of the moral sense were associated with physical abnormalities of the brain and could be identified by the contours of the skull. Those theories were eventually discredited, but there was continued widespread acceptance of the related notion that criminality could have biological roots.

Most writers recognized a continuum between the two extremes, suggesting an evolutionary scale. Those incapable of change were at the bottom, with offenders ranked above them depending upon degrees of inherent abnormality. Those at higher levels offered far greater potential for reform when they were exposed to positive influences. ${ }^{87}$

While prison officials expressed confidence that they could identify the most seriously incorrigible by behavior and attitude, the child-saving movement was influential in advocating that the age of the offender be considered as most significant. Under common law, the defendant's age had long been an important factor, with courts recognizing a presumption that a child under the age of 14 was incapable of acting with criminal intent. As reformers grew more concerned about the increasing number of juvenile offenders, they cited theories of mental and emotional development that were consistent with the legal rule, and stressed the importance to children of education and positive parental guidance. ${ }^{88}$ A child who was deprived of those beneficial influences was more likely to be maladjusted and far more prone to delinquency and criminal behavior. Most commenta-

86. See Koons, “Wesley Elkins,” 5.

87. Rafter, Creating Born Criminals, 121.

88. See Blomberg and Lucken, American Penology, 88. 
tors accepted that physiology could also play a role, but they insisted that even children with inborn criminal tendencies were malleable enough to be properly trained, given early intervention and effective support. ${ }^{89}$

According to one writer in 1898, "Environment of the right sort may do much to correct any of the recognized vices of heredity," and that optimistic view was widely accepted. ${ }^{90}$ Yet the role of "nature" was never completely discredited. In fact, by the beginning of the twentieth century, the image of the born criminal was triggering a new and heightened public fear.

Identifying themselves as criminal anthropologists, European scientists had previously suggested the existence of a separate criminal class that was physically and psychologically different from other people. By the late 1890s, American writers were advancing those theories, describing inherited abnormalities that would be passed down through the generations. Born criminals were now described not only as victims of their biological makeup, but, more significantly, as carriers of the mental defect that inevitably led to crime. At a time of widespread social problems - immigration, poverty, urban squalor, and disease - the danger that society could be further weakened by propagation of the criminal class seemed a serious threat. ${ }^{91}$

As the new century dawned, some scientists suggested that relying on evolutionary theory could reduce crime and strengthen future generations. Specific techniques were devised to diagnose criminals, then to segregate them into defective types. For those identified as born criminals, permanent incarceration was now seen as necessary to protect society from their acts, as well as to prevent their reproduction. ${ }^{92}$

During the final years of debate over Elkins, eugenic thinking was in its early stages. As the twentieth century progressed, eugenics would be harnessed to justify more radical policies, culminating in the brutal race-based strategies of the Nazis and

89. Ibid., 83-89; Platt, The Child Savers, 18-45.

90. Platt, The Child Savers, 52, quoting a statement by Henry D. Chapin at the National Conference of Charities and Correction in 1898.

91. Rafter, Creating Born Criminals, 110-32; Platt, The Child Savers, 18-45.

92. Rafter, Creating Born Criminals, 123-24. 
indelibly linking the field to ideological fanaticism. ${ }^{93}$ In the early 1900s, though, such ideas were just emerging, and the central principle - that society could be improved by preventing reproduction by selected individuals - stimulated new arguments against Elkins. The possibility that he would have children, passing on his inherited criminal disposition to future generations, was now put forth as one of the most dangerous risks of his release. ${ }^{94}$

Further complicating the matter, Iowa politics were tumultuous in 1901, characterized by bitter infighting within the controlling Republican Party. ${ }^{95}$ Senator Gear's death just five months after his re-election in January 1900 had triggered dissension. Despite evidence that he had promised the position to Albert Cummins, Governor Shaw abided by the wishes of the conservatives and appointed Jonathan Dolliver to finish Gear's term. That rejection proved to be too much for Cummins and his progressive supporters. In a bold move, Cummins announced that he would campaign for the Republican nomination for governor, mobilizing his large personal following to challenge conservative leaders. After a vigorous campaign throughout Iowa, denouncing the corrupting influence of special interests on state government before enthusiastic audiences, Cummins went on to win the Republican primary in August and the general election in November. He continued as governor until 1908, when he was elected to the U.S. Senate; his strong leadership in Iowa reflected a significant change in the state's political climate, consistent with the trend toward progressivism throughout the country.

\footnotetext{
93. For discussions of eugenics in the twentieth century, see Aaron Gillette, Eugenics and the Nature-Nurture Debate in the Twentieth Century (New York, 2007); Edwin Black, War Against the Weak: Eugenics and America's Campaign to Create a Master Race (New York, 2003); and Amy Vogel, "Regulating Degeneracy: Eugenic Sterilization in Iowa, 1911-1977," Annals of Iowa 54 (1995), 119-43.

94. Des Moines Daily Capital, 4/2/1902.

95. For the struggle within the Republican Party during these years, and the rise of progressivism in Iowa and elsewhere, see Benjamin F. Gue, A History of Iowa (New York, 1903), 205-7; Fleming Fraker Jr., "The Beginnings of the Progressive Movement in Iowa," Annals of Iowa 35 (1961), 578-93; Nye, Midwestern Progressive Politics, 210; and Leland Sage, A History of Iowa (Ames, 1974), 216-33.
} 
In the late fall of 1901, when it was clear that Governor Shaw would not be running for re-election, Harlan wrote to remind him of his promise to forward a pardon request from Elkins to the General Assembly. Despite his personal objections, Shaw abided by his word. Setting a new record, Shaw forwarded 13 appeals from convicted murderers for review, including one received from Elkins. ${ }^{96}$

In early January, Albert Cummins was inaugurated as governor. ${ }^{97}$ Legislators were in town for the festivities and for the start of the Twenty-ninth General Assembly. Throughout the spring, people continued to come to Des Moines from locales throughout the state to make their views known to their representatives.

In the early months of 1902, women were especially in evidence in the capital, eager to advocate for causes that were of particular interest to them. Hundreds attended the three-day meeting of the state chapter of the National Congress of Mothers in late January, visiting the statehouse to argue for compulsory education laws and a juvenile court system. A month later, women crowded into the legislative galleries to hear the senate debate the woman suffrage bill. Supporters celebrated victory after the vote in the senate, only to be bitterly disappointed a month later, when the bill was defeated in the house. Newspapers vividly described the statehouse scene, with women filling the galleries and even crowding into the cloak rooms, and then forming an angry "stampede" into the corridors after the vote. ${ }^{98}$

The pardon for Elkins would be another controversial topic for debate in 1902: the Des Moines Daily Capital had begun to publicize the case in November, Professor Harlan was expected to champion Elkins's cause again, and Senator Hiram Bishop declared that Clayton County would stand firm in its opposition,

96. James E. Harlan to Governor Leslie M. Shaw 10/28/1901, Elkins Archives; Des Moines Daily Capital, 1/15/1902; Iowa State Register, 11/21/1901. By contrast, only four applications had been forwarded for legislative review two years earlier. Semi-Weekly Cedar Falls Gazette, 1/9/1900. When the report of pardons and paroles was made public in mid-January 1902, Governor Shaw was widely criticized for the apparent increase in leniency, and the General Assembly was urged to act with great discretion when it considered the applications of the 13 convicted murderers. Des Moines Daily News, 1/15/1902.

97. Davenport Daily Republican, 1/16/1902; Des Moines Daily News, 1/16/1902.

98. Des Moines Daily News, 1/27/1902, 1/28/1902, 2/26/1902, 3/13/1902. 
with 90 percent of residents having already signed new petitions on the matter. ${ }^{99}$

As in 1898, Elkins was his own best advocate. His writings were circulated to legislators and to the public. This time, he addressed a letter directly to "The Citizens of Clayton County," expressing his remorse for his past actions and pleading with them to "thoroughly investigate my conduct, record, my present mental and moral condition, before taking any action adverse to my release." He described how education had changed him and developed his moral consciousness, so that "the evil tendencies ... in the boy [have] been permanently eradicated in the man." And he begged the people of Clayton County to act with Christian charity, "to temper justice with mercy," and to give him the chance to rejoin society and prove that he could "live in obedience to the law of the land, and in harmony with the law of God, and with the rightful claims of my fellow men."100

An editorial in the Arlington News (the newspaper in a small town in Fayette County, just a couple of miles west of the Clayton County boundary), reprinted in the Des Moines Daily Capital, purported to respond to Elkins on behalf of the citizens of Clayton County, warning him that they would not be deceived by his claims. "Sentimentalists" might be swayed by his educated words, but not those who remembered his awful bloody crimes and then his lies, when he had "gone about town talking about the affair as if a couple of rabbits had been slain." People in Clayton County would not be fooled by Elkins now.

If young Elkins is doing so well in the prison, is studying so ardently, is so well demeanored and behaved and is making a man of himself at such rapid strides, it would be cruel to let him out and thereby subject him to the temptations and pitfalls of a wicked world and the liability of a downfall. He is young yet and the proper place for him is undoubtedly where he is in the prison.

When ... desperadoes and murderers [such as Elkins] are once safely in the penitentiary what in the name of common sense is the use in taking chances by letting them out. Let them alone. ${ }^{101}$

99. Des Moines Daily Capital, 11/1/1901, 1/15/1902.

100. J. Wesley Elkins to Citizens of Clayton County, 1/6/1902, Elkins Archives. 101. Des Moines Daily Capital, 2/12/1902 (reprinted from Arlington News). 
Through the first months of 1902, the Elkins case attracted excited attention, and supporters were well organized to make the case on his behalf. Harlan visited the capitol, meeting with legislators individually and offering interviews to reporters. Committee members who traveled to Anamosa reported that they were positively impressed by Elkins, a "young man of great intelligence and thoroughly well educated." Newspapers reprinted letters from Elkins and commendatory reports from Anamosa. One morning legislators found small pamphlets on their desks, featuring a photograph of Elkins as an 11-year-old schoolboy. Inside were statements from the wardens and the letter from Elkins addressed to those in Clayton County. ${ }^{102}$

The house and senate Committees on Pardon moved forward with their investigations, holding joint sessions to interview prison administrators, Professor Harlan, and Clayton County residents. Supporters were surprised by the continuing intense opposition, and they began to accept conditional release as the best solution. A resolution recommending parole rather than pardon was drafted, and Professor Harlan offered his assurance that he would personally take charge of Elkins. In a letter addressed directly to the legislators, Elkins agreed "to be placed under the tutelage of Prof. Harlan," and "with all my strength endeavor to meet every condition in spirit and in deed. ... If my young life is ever to be turned into an avenue of usefulness ought it not to be now, while I am young and strong and hopeful of the future? Why not now before incentive to action is lacking and spirit of ambition departs leaving behind a weary, hopeless wreck?" 103

In late March, a long article appeared in the Des Moines Daily Leader, reporting "new objections" to releasing Elkins. Actually, the arguments had been made before - that Elkins was a born criminal whose degeneracy could not be "educated or cultivated out of him" - but this time the stories about his mother, circulating for years in Clayton County, were reported to a wider audience to explain the "violent prejudice" against Elkins. ${ }^{104}$

102. Davenport Daily Republican, 3/12/1902; Des Moines Daily Capital, 3/14/1902. 103. Des Moines Daily Capital, 3/1/1902; Anamosa Eureka, 4/10/1902; Mt. Vernon Hawkeye, 3/28/1902.

104. Des Moines Daily Leader, 3/19/1902. 
Elkins's crimes were now more overtly blamed on heredity, and the idea of him as a carrier of criminality was made more explicit: he was "born with the brand of Cain on his brow" and would forever be a menace to society. Clayton County residents were convinced that he would kill again if released, and even greater danger could result if he were allowed to reproduce: "The degeneracy of Wesley Elkins is firmly believed by the people of Clayton County to be a verification of the Mosaic prophecy that the sins of the fathers shall be visited upon the children, even unto the third and fourth generations."

In late March, when the house and senate Committees on Pardon finally voted on the resolution to parole Elkins, the majority was against him. Only a single vote separated the two sides in both committees, but it seemed that the question would once again be resolved without debate on the floor of the General Assembly. Elkins's supporters argued, however, that the close votes and public attention warranted a discussion by the full legislature, and other committee members agreed. ${ }^{106}$

Newspapers predicted that the Elkins case would inspire some of the most emotional speeches of the entire session. When the senate convened on the morning of April 2, with the matter first on its agenda, the gallery was crowded with spectators filling the seats and standing along the walls. Sentiment in the audience, increasingly obvious as the day wore on, was almost unanimous in favor of Elkins. ${ }^{107}$

Senator William Whipple, chair of the Committee on Pardons, made the first extended speech, offering the minority report in favor of Elkins's release. He read aloud the terms that would apply to Elkins during his parole: requiring him to avoid evil associations, obey the laws, and abstain from intoxicating liquors for ten years. Violation of any of the terms would send him back to prison. If he complied, he would be granted a full pardon at the end of the ten-year period. ${ }^{108}$

105. Ibid.

106. Des Moines Daily News, 3/22/1902, 3/28/1902.

107. Des Moines Daily Capital, 4/2/1902; Anamosa Eureka, 4/10/1902.

108. Des Moines Daily Capital, 4/2/1902. 
Whipple was new to the senate, but he was an experienced lawyer and a persuasive advocate. He began with the facts of the crimes but focused on details that were not widely known. Relying on testimony from neighbors at the inquest, Whipple described the boy's life with his mother, his trip alone to Clayton County after her death, the mistreatment he had suffered at the hands of his father and stepmother, and, finally, his unsuccessful attempt to run away. Whipple appealed to his colleagues to imagine themselves in the boy's position: isolated from friends and family, capable of only the most crude and immature reasoning, and desperate to escape. Common sense would suggest that a child, under such circumstances and at such a young age, was not capable of adult reasoning. Whipple explained that legal precedent supported that conclusion, so that the life sentence was illegal and unjust. ${ }^{10}$

As other supporters had, Whipple emphasized Elkins's transformation in prison as the most persuasive reason for his release. He closed by reading aloud one of Elkins's letters, declaring it more erudite than any legislator could compose. According to the newspapers, the letter produced a "profound impression" on the audience; many were moved to tears. Whipple's address was later said to be "one of the most masterly speeches of the session," establishing him as a leader in the senate in the years to come. ${ }^{110}$

Senator Hiram Bishop from Clayton County responded with the case against Elkins, referring to him as Dr. Jekyll and Mr. Hyde: the split personality with the good side masking the evil within. Elkins presented himself now as Dr. Jekyll, with his handsome countenance and educated words. But his true character - as the evil Mr. Hyde - was proved by his appalling crimes. As Bishop described the bloody details, he acted out the role - reaching below the table to bring forth a wooden club, stained with dark spots, and raising it dramatically over his head.

109. Cedar Rapids Republican, 1/19/1902; Des Moines Daily Capital, 4/2/1902; Iowa State Register, 4/3/1902. Senator Trewin made the same legal point, citing specific court cases in support. Trewin's argument was especially persuasive to many legislators. Des Moines Daily News, 4/3/1902; Iowa State Register, 4/8/1902. 110. Des Moines Daily Capital, 4/2/1902; Cedar Rapids Republican, 4/6/1902. 
In thunderous tones, Bishop declared that the club was the actual weapon Elkins had used to beat his stepmother to death, striking her numerous times about the face and on her legs. ${ }^{111}$

Senator Bishop challenged the idea that a true degenerate could ever change; an individual who had inherited evil tendencies was beyond all hope of redemption. Born to a wicked mother, Wesley Elkins was such a person, and the possibility that he would produce similarly infected offspring was the most serious issue of all. Bishop exhorted his listeners to oppose Elkins's release on any terms.

Bishop's speech was not as well received as he had hoped. Some objected to his display of the weapon, his hyperbolic language, and his reliance on local rumors, charging that he was appealing to prejudice and fear instead of invoking rational judgment. A number were troubled by reports from 1898 that Elkins had been promised release in 1900, assuming two more years of good behavior. Bishop's criticism of Professor James Harlan, sometimes referred to as "one of the most beloved men in all of Iowa," may have also hurt his cause. The Cedar Rapids Republican reported Bishop's verbal attack on the professor, sneering at him as a sentimentalist who was "dwelling in an atmosphere of exclusiveness that [makes] him unfit for the practical things of the world."

Throughout the day, senators rose to express their views. Several agreed with Bishop, while others condemned the intolerance and narrow-mindedness that seemed to underlie the opposition. By the end, the arguments supporting Elkins proved to be most convincing. The final tally, taken late that afternoon, was 27-20 in favor of the resolution recommending parole. ${ }^{114}$

The house opened its debate the following morning, and, as in the senate, speakers addressed a crowded gallery. Elkins's supporters were optimistic, reporting that favorable sentiment was even stronger in the house than in the senate. ${ }^{115}$ The argu-

111. Des Moines Daily News, 4/2/1902; Anamosa Eureka, 4/10/1902.

112. Des Moines Daily Capital, 4/2/1902.

113. Iowa State Register, 4/3/1902; Cedar Rapids Republican, 4/6/1902.

114. Iowa State Register, 4/2/1902; Des Moines Daily Capital, 4/3/1902.

115. Cedar Rapids Evening Gazette, 4/4/1902; Des Moines Daily Capital, 4/3/1902. 
ments, lasting all day, had been heard before, but the speakers were passionate and emotional in their presentations.

Elkins's supporters cited legal precedent on his side, but they relied less on detached analysis than on appeals for empathy and compassion. Dr. Bert Eiker, a 30-year-old physician from Decatur, refuted the idea that criminality could be passed from a mother to a son and then urged his colleagues to imagine and remember how unformed was the mind of an 11-year-old child. He had brought photographs of Elkins at that age, and he called on a young page named Bertie Winslow - also age 11 to distribute the pictures throughout the gallery. Bertie Winslow was a great favorite in the house, described in a newspaper report as "the picture of childish innocence and honest, open frankness." As Winslow came forward, Eiker called the boy to his audience's attention. "I want you to remember that this boy here ... is of exactly the same age, is of about the height and build as was Wesley Elkins at the time the crime was committed. I ask you if this boy were this night to commit a crime so foul as the one committed by Elkins, would you - could you, declare that he was capable of discerning between right and wrong and of clearly reasoning the duty and relations he owes to his fellow man?

Many speakers relied on personal experiences to remind the audience of a child's emotions, "the strength of passion ... and the unreasoning rage which might easily prompt deeds of violence." In a particularly memorable speech, Colonel Samuel Moore, the oldest representative at the age of 81 , recounted an incident from his own childhood, telling how he had been "beaten and abused" by boys who were physically stronger than he. Listeners wiped away tears as Colonel Moore described his oppression and his overwhelming anger, how he had been driven "to desperation" and had come close to violence. Even now he remembered the difficulty of maintaining self-control, and the provocations in Elkins's childhood were so much more severe. ${ }^{117}$

Opposition to Elkins's parole was led by J. C. Flenniken, one of the few Republicans to be elected from Clayton County. Flen-

116. Des Moines Daily Capital, April 3, 1902.

117. Cedar Rapids Evening Gazette, 4/4/1902. 
niken was in his first term, but he worked hard to make friends in the house. Some had already pledged to vote with him, so he was optimistic that the final roll call would go his way. As a jewelry tradesman, Flenniken had little experience as a public speaker. As expected, he emphasized the passionate feelings in his county and demanded that those views be respected. He relied on the Des Moines Daily Leader article to make his points, reading aloud the stories about the rumors and fears in Clayton County, continuing even while the audience grew distracted. Finally, the Speaker of the House rapped his gavel to call time. After consulting with other representatives, the Speaker allowed Flenniken to continue, but Elkins's supporters whispered among themselves that the interruption had significantly weakened the power of his speech. ${ }^{118}$

Flenniken, however, had been effective in his lobbying efforts. When the vote was called late that afternoon, the numbers were far closer than predicted. Observers, almost unanimous in their support for Elkins, kept track as names were called, expressing distress as the count against Elkins increased. When the final result was announced, many in the audience wept. The resolution recommending parole for Elkins was defeated by a single vote, with 47 against and 46 in favor. ${ }^{119}$

Within a few minutes, though, there was a motion on the floor for reconsideration, supported by two representatives who had voted against parole. ${ }^{120}$ One of them said that he had pledged his vote to Flennikin, but now, having fulfilled that promise, he wished to change his position. ${ }^{121}$ Apparently, others were also having second thoughts. The motion to reconsider passed by a

118. Des Moines Daily Capital, 4/4/1902; Clayton County Centennial, 7/1/1936; "Notable Deaths," Annals of Iowa 22 (1941), 592; Des Moines Daily Capital, 4/3/ 1902.

119. Des Moines Daily News, 4/4/1902.

120. Ibid. The two representatives who proposed the reconsideration were H. E. Teachout, from Polk County, and John Jenks, from Pottawattamie County; Teachout voted for Elkins's parole the second time, and Jenks was absent when the second vote was called the next morning.

121. Emory H. English, "Thirty-Second Biennial Meeting of Iowa Pioneer Lawmakers," Annals of Iowa 32 (1953), 24 (Burton Sweet address, "Iowa Legislature Fifty Years Ago"); Des Moines Daily Capital, 4/5/1902 (reporting others who had been pledged to Flenniken on the first vote and then changed their minds). 
large margin, and the Speaker announced that a second vote on the main resolution would be called the next day. ${ }^{122}$

Elkins's friends spent the evening conferring with opponents. Some of those men were conspicuously absent from their desks when the vote was called the next morning. Even Flenniken realized that the tide had turned. In the end, the number in favor of Elkins increased by only two, but the total opposed fell sharply. With the final tally at 48-35, the Speaker proclaimed that the resolution had passed, so the house would recommend Elkins for parole. Within minutes, a telegram was dispatched to Anamosa with the news. ${ }^{123}$

A few days later, Senator Whipple requested that a final letter from Elkins be read aloud on the senate floor. As the Daily Capital reported the scene,

A death-like-stillness followed as the letter was placed in Secretary Newman's hands by a page. He commenced the reading of the communication in a clear, firm voice, but before he had proceeded far his voice broke and he was compelled to stop and regain composure before he could proceed....

And not all of the senators sat with dry eyes. There was more than one who gave evidence of being strongly moved as the pledge of the young man to go forth from the prison walls and demonstrate the wisdom of the action of the legislature in his behalf was read. ${ }^{124}$

In most of the state, especially the capital and places where Professor Harlan was well known, the public reaction to the decision on Elkins was overwhelmingly positive, with some newspapers condemning the opposition's exaggerated fears and others proclaiming that Elkins's imprisonment was illegal from the beginning. The citizens of Clayton County, however,

122. Des Moines Daily Capital, 4/5/1902, 4/4/1902.

123. Des Moines Daily Capital, 4/5/1902, 4/4/1902; Iowa State Register, 4/3/1902. Susan Glaspell published a short story, "In the Face of His Constituents," in Harper's Magazine in October 1903, that roughly recreates the debate in the Iowa senate about Elkins's fate. The story, renamed "The Plea," appeared in Glaspell's first story collection, Lifted Masks (New York, 1912). See Patricia Bryan, "Foreshadowing 'A Jury of Her Peers': Susan Glaspell's 'The Plea' and the Case of John Wesley Elkins," in Susan Glaspell: New Directions in Critical Inquiry, ed. Martha Carpentier (Cambridge, 2006).

124. Des Moines Daily Capital, 4/5/1902. 
reacted angrily to the harsh criticism of their views and the denigration of their fears. According to reports, residents there suggested that Elkins be reminded that he had been convicted only for the murder of his father: "It is no secret that the Clayton county authorities may arrest Elkins if they get hold of him. ... The indictment [for the murder of his stepmother] still hangs over him and there is little or no disposition on the part of his old neighbors to forget it or forego it. If they could bring Elkins back, he would be brought . . . to this county in short order and put on trial again." ${ }^{125}$

In mid-April Governor Cummins signed the papers authorizing Elkins's release. Most of the terms were incorporated from the legislative resolution and were typical in paroles - requiring moral conduct, abstention from intoxicating liquors, and monthly reports - but the governor added two other provisions that were unique to Elkins. Unless granted permission otherwise, he was required to live in Linn County, close to Professor Harlan. Perhaps out of concern for his own protection as much as to guard the safety of others, he was prohibited from entering Clayton County or any county adjoining it. If Elkins complied with the conditions for ten years, he was promised a full pardon. ${ }^{126}$

Dressed in new clothes - a dark blue serge suit, a blue batwing tie, and a fawn fedora hat - and with 13 dollars in his pocket, Wesley Elkins finally walked out of the State Penitentiary at Anamosa early on the morning of Saturday, April 19, 1902. He was escorted first to the warden's office, where Professor

125. Iowa State Register, 4/5/1902; Des Moines Daily Capital, 4/5/1902; Anamosa Eureka, 4/10/1902; Mt. Vernon Hawkeye, 4/14/1902; Des Moines Daily Capital, 4/15/1902 (quoting from the Elkader Argus); Anamosa Eureka, 4/10/1902 (quoting a communication from McGregor to the Cedar Rapids Republican).

126. Des Moines Daily News, 4/18/1902; Albert B. Cummins, Pardon of John Wesley Elkins, 4/14/1902, Elkins Archives; Des Moines Daily Capital, 4/17/1902. Elkins was one of a record number of life prisoners released from Iowa prisons in the spring of 1902 (as opposed to three lifers released in 1898 and only two in 1900). Cedar Rapids Weekly Gazette, 4/14/1902. Out of the 13 inmates it considered in 1902, the General Assembly recommended seven of them, and Governor Cummins agreed to conditional paroles for all seven. Des Moines Daily News, 4/11/1902. The Anamosa Prison Press (4/12/1902) rejoiced that freedom was granted to so many serving life sentences, but many outside the prison criticized the significant increase as a display of excessive leniency and an abuse of power, with the lengthy legislative debates described as a wasteful use of valuable time and resources. Des Moines Daily News, 4/21/1902. 


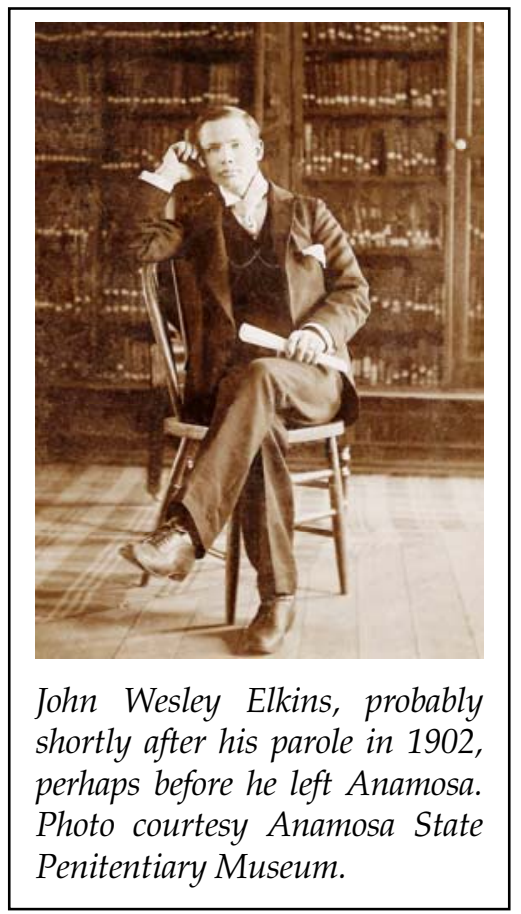

Harlan was waiting with the warden's private secretary, the warden's brother, and a reporter from the Des Moines Capital. Elkins stood while Warden Hunter read aloud the conditions of the parole and requested his agreement to abide by the terms. Elkins tried to speak but the words would not come, so he finally nodded in assent. Warden Hunter grasped his hands and offered hearty congratulations. ${ }^{127}$

With Harlan by his side, Elkins walked down the stone steps at the front of the penitentiary to the waiting horse-drawn buggy. At the street, Elkins turned to gaze up at the building, commenting to Harlan that he had never seen it from the outside before. As the buggy started to move away, an armed guard, elevated high in a guardhouse above the street, watched. Raising his gun to present arms, a traditional military salute to show respect, he shouted out a final farewell to Elkins. ${ }^{128}$

127. Des Moines Daily Capital, 4/19/1902, 4/21/1902.

128. Des Moines Daily Capital, 4/21/1902. See also James E. Harlan to John Briar, Private Secretary to the Governor, 4/26/1902 (which confirms some of 
THE PUBLIC DRAMA of Wesley Elkins's life came to an end with his release from prison. His monthly reports to the governor describe a quiet existence. ${ }^{129}$ He lived with the Harlans for several months, working in their garden and taking odd jobs with neighbors to pay his rent. In the fall, he enrolled in high school classes at the Cornell Academy, including bookkeeping and stenography, and worked part-time in a dry goods factory. He joined the Gladstone Literary Society and participated in debating competitions. His name appeared in reports on the contests in the college newspaper, and his picture was included in the yearbook, but he sought to keep a low profile. ${ }^{130}$

During the summer of 1903, Elkins visited relatives in Minnesota, and, in the fall of 1904, the governor agreed to his request to move there. Elkins expressed his love and respect for Professor Harlan, but he wanted to be financially independent, and he was also anxious to leave the state where his name was so well known, associated in so many minds not only with his tragic past, but also with the suggestion of hidden depravity. ${ }^{131}$

Elkins never lived in Iowa again. He traveled to the state several times each year, visiting Harlan and others who had supported him in the legislature, but he maintained his residence in St. Paul. After high school, he found a full-time position as an accountant in the offices of a railroad, and in 1909 he was proud to announce that he had purchased his own home, at a cost of $\$ 3,350 .{ }^{132}$

these details and identifies the newspaperman present in the warden's office as Mr. Moorhead of the Des Moines Daily Capital), Elkins Archives.

129. These letters, starting April 19, 1902, and ending on April 19, 1912, are in the Elkins Archives.

130. "Irving-Gladstone," Cornellian, 12/5/1903 (noting that "Mr. Elkins' hesitation at times detracted to a certain extent from the effectiveness of his argument"); Royal Purple '05, 126, 140, Cornell College Archives, Mt. Vernon, Iowa.

131. Wesley Elkins to James Harlan, 9/10/1904, Elkins Archives; Marble Rock Journal, 8/20/1903 (reporting that supporters had come to believe that "the only way that the young man . . . can have a chance at all is for him to change his name and go where neither his crime nor himself is known").

132. All of these details are from letters from Wesley Elkins to the governor of Iowa from April 1902 to April 1912. The house Elkins purchased was at 1918 Ashland Avenue in St. Paul. 
In March 1912 Harlan received the papers granting Elkins an unconditional pardon. The ten-year period would expire in April, but the governor hoped to avoid publicity by issuing the documents early. ${ }^{133}$ Harlan notified Elkins, who requested that the papers be sent under ordinary cover rather than special delivery to avoid attention. He also asked Harlan to try to keep the news out of the Iowa papers and to take special care not to disclose his current address to anyone in Clayton County. ${ }^{134}$

Elkins lived for almost 60 years after he left prison, but he becomes more difficult to trace once his monthly letters to the governor stopped in 1912. Records show that he lived in St. Paul until at least 1920, and then moved far away, to Honolulu, Hawaii. ${ }^{135}$ In 1922, at the age of 44, he married a 29 -year-old woman named Madeline Kahaleuluohia Lazarus, and the couple eventually relocated to San Bernardino County, California. ${ }^{136}$ Elkins went by his first name, John - the same as his father's - and owned a chicken farm, while his wife worked as a stenographer at a nearby military base. Death certificates record the end: Madeline Elkins died from a heart attack in 1959; John Wesley Elkins died two years later, at the age of 83, with his death attributed to heart disease. ${ }^{137}$ When a short obituary was published, it noted only that Elkins had lived in the area for 33 years. As he would have wished, nothing was included about his early years: his sad childhood, his conviction for murder, the 12 years he spent in prison, or his decade-long fight for freedom. ${ }^{138}$

133. Governor B. F. Carroll to James E. Harlan, 3/28/1912, Elkins Archives. 134. Wesley Elkins to James Harlan, 4/4/1912, Elkins Archives.

135. 1920 U.S. Census, Minnesota (vol. 68, sheet 9, line 80), listing John W. Elkins living at 1918 Ashland Avenue in St. Paul; Cornell College Register, 18531925, 11/30/1925, Cornell College Archives.

136. See records indexed at Family Search Database, www.familysearch.org.

137. Certificate of Death, Madeline Kahaleuluohia Elkins, County of San Bernardino, 3/12/1959 (recording John W. Elkins as current husband, last occupation as stenographer, and 31-year residence in the county); Certificate of Death, John Wesley Elkins, County of San Bernardino, 3/7/1961 (recording Madeline Elkins as deceased spouse, last occupation as self-employed poultry man, and 33-year residence in the county).

138. San Bernardino Sun, 3/10/1961. 